sent serious ethical and economic problems. The measurement of cell colony formation and survival, the only legitimate end point, is irrevocably time consuming. However, as further retrospective and prospective correlation data accumulates, the stem cell assay time of two to three weeks may provide a stimulating field of research designed to identify parameters which could be used to shorten the time involved.

\section{Rejecting ophiolites}

\section{from Peter J. Smith}

LINEAR marine magnetic anomalies must be due to magnetised material beneath the ocean floors. But that is to put the matter at its simplest and least instructive. What is the composition of the suboceanic material? How thick is it? How deep is it? How strongly magnetised is it? And what are the shapes of the magnetised segments that account for the alternating pattern of positive and negative anomalies? Taken together, these questions define a major problem-and one that must be solved if the correlation between marine anomalies and reversals of the geomagnetic field is to transcend mere phenomenology.

One approach to the problem is to model the anomaly-producing oceanic lithosphere; but however well a model predicts the observed anomalies it cannot provide a unique solution, still less one likely to correspond with reality. Nor can it provide a complete solution. The only way of doing that is to sample the oceanic lithosphere. In practice, however, direct sampling has produced only an incomplete, and thus confusing, set of data because the Deep Sea Drilling Project (DSDP) has thus far achieved a maximum penetration of only $0.6 \mathrm{~km}$ into the suboceanic igneous basement. Two recent expeditions to the mid-Atlantic ridge, for example, have obtained magnetic data suggesting that a magnetised layer of $500-1,000 \mathrm{~m}$ may be sufficient to account for the anomalies there. Away from spreading centres, on the other hand, samples are usually much less intensely magnetised, cores sometimes contain material magnetised in a sense opposite to that necessary to produce the observed anomaly, and the igneous column is often contaminated with sediment and voids. Magnetic layer thicknesses of up to $2.5 \mathrm{~km}$ or more are

Peter J. Smith is a Reader in the Department of Earth Sciences at the Open University. therefore apparently required to account for some observed anomalies.

Presumably time and money will ultimately allow direct sampling to answer all relevant questions. In the meantime, however, some workers have suggested that a solution may be sought in ophiolite complexes, those sequences of rock types widely supposed to represent oceanic lithosphere now upthrust on to land. It is an enticing thought, for if such speculations about their origin are correct, ophiolite suites at present offer the only direct access to deeper sections of the oceanic lithosphere. But as Levi et al. (Geophys. Res. Lett. 5, 473; 1978) now point out, there are dangers in taking so simplistic a view. For one thing, ophiolites are obviously older than they were when part of the in situ oceanic lithosphere, and some are older than any existing ocean floor. Second, it is by no means clear whether they represent lithosphere as formed at a spreading axis, as modified in fracture zones or as altered by subduction processes-or whether all three types exist. Then again, many ophiolite suites have been altered to a greater or lesser extent. But when did the metamorphism take place-in the original oceanic environment, during upthrust on to continent, or since this emplacement occurred?

As far as magnetic studies are concerned such matters are of vital importance, for magnetic minerals are very sensitive even to moderate heating for very short periods. Levi and his colleagues therefore suggest that before too many workers uncritically attribute the magnetic characteristics of ophiolite complexes to inaccessible parts of the oceanic lithosphere it would be useful to have a set of criteria by which ophiolites might be deemed suitable or unsuitable for modelling the magnetic properties of the layers responsible for marine magnetic anomalies.

Because the DSDP has only achieved a $0.6 \mathrm{~km}$ penetration of the igneous lithosphere, direct comparison between the present oceanic lithosphere and ophiolites can only be carried out in respect of the latter's upper pillow basalts and associated flows. Levi and his coworkers propose, therefore, that if an ophiolite complex is to be used to model the magnetic properties of the oceanic lithosphere, at the very minimum the magnetic characteristics of the complex's upper extrusives should correspond closely to those of submarine basalts from today's oceans. Specifically, this means that the extrusives should have Curie points in the range $100-459^{\circ} \mathrm{C}$, intensities of magnetisation $>10^{-4}$ gauss, ratios of remanent to induced magnetisation $>1$, and no alteration beyond zeolite facies metamorphism.
These are, of course, necessary, but not sufficient, conditions. Even if the minimum criteria were satisfied there would be no guarantee that any given ophiolite complex would be completely suitable. Nevertheless, the application of just the minimum conditions has a devastating enough effect, as examination of six ophiolite suites shows. The Vourinos complex of central Greece is eliminated straight away because its pillow lava sequence is missing. The Smartville (California) complex has pillow lavas but they conform to none of the four criteria. The Oman Massif and Othris (Greece) complexes are more difficult to interpret but disobey at least one criterion. The only complexes conforming to all four criteria are those from Macquarie Island and the Troodos Massif (Cyprus). All of which suggests that, magnetically speaking, ophiolites may not be quite the help they once appeared.

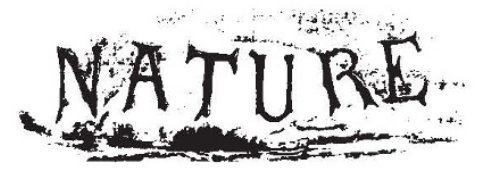

\section{A hundred years ago}

THE medical students of Paris have not forgotten that Rousseau was a botanist as well as a philosopher, and sent a delegation on July 2 to Ermenonville to celebrate the 100th anniversary of his death. Three addresses were delivered in the name of the medical body-one by Dr Bergeron, the toxicologist, the second by $M$. de Lannessau, and the third by M. Baillon, himself a botanist and a professor of the School of Medicine. The speakers referred in eloquent terms to the love of Rousseau for nature, his observational genius, and his works on botany. The students had prepared a spendid crown made of pervenches (periwinkle. Vinca) the flower which Rousseau loved best, and which had been collected by them in the very forest where the philosopher spent his last years. As no boat was to bc had to reach the island where the author of the "Nouvelle Héloise" is buried, one of the students threw himself into the water and swam with the testimonial to the spot sacred to the memory of the impulsive Frenchman.

From Nature 18, 25 July, 345; 1878. 